\title{
Histopathology of oedema in pearl oysters Pinctada maxima
}

\author{
J. B. Jones*, M. Crockford, J. Creeper, F. Stephens \\ Department of Fisheries, PO Box 20, North Beach, Western Australia 6920, Australia
}

\begin{abstract}
In October 2006, severe mortalities (80 to $100 \%$ ) were reported in pearl oyster Pinctada maxima production farms from Exmouth Gulf, Western Australia. Only P. maxima were affected; other bivalves including black pearl oysters $P$. margaratifera remained healthy. Initial investigations indicated that the mortality was due to an infectious process, although no disease agent has yet been identified. Gross appearance of affected oysters showed mild oedema, retraction of the mantle, weakness and death. Histology revealed no inflammatory response, but we did observe a subtle lesion involving tissue oedema and oedematous separation of epithelial tissues from underlying stroma. Oedema or a watery appearance is commonly reported in published descriptions of diseased molluscs, yet in many cases the terminology has been poorly characterised. The potential causes of oedema are reviewed; however, the question remains as to what might be the cause of oedema in molluscs that are normally iso-osmotic with seawater and have no power of anisosmotic extracellular osmotic regulation.
\end{abstract}

KEY WORDS: Oedema $\cdot$ Pinctada maxima $\cdot$ Osmosis $\cdot$ Lesion · Mortality

\section{INTRODUCTION}

The annual value of production of the pearling industry prior to 2008 was about 120 million Australian dollars, and the industry formed one of the most valuable aquaculture industries in Western Australia. The industry was also a major rural employer. The pearling grounds are remote and extend from Exmouth Gulf in the west to the Northern Territory border in the east, a linear distance of some $1750 \mathrm{~km}$ (Fig. 1). Exmouth is $1130 \mathrm{~km}$ from Perth, the capital and only major population centre in Western Australia. Prior to the 2006 mortalities, Exmouth Gulf was considered to be a good area for growth of juvenile Pinctada maxima. Pearl quality was enhanced if seeded shell was transported to farms in the north of the state.

The pearling industry in Western Australia was previously affected by severe mortalities in the 1980s that were found to be due to Vibrio spp. infections associated with poor management practices (Pass et al. 1987). Since that time, the industry has been aware of the threat of disease and a complex series of transport protocols and separation of pearl farm lease areas has been required (Jones 2008). Equipment used by seeding technicians is sterilised when moved between farms according to an industry-agreed protocol. Farms are generally not permitted to be within 5 nautical miles of another company and shell is required to have a health certificate before movement from hatcheries or between zones in the fishery. As a result of this certification activity, pathologists from the Department of Fisheries histologically examine up to 10000 oysters annually, and many incidental parasites have been recorded (Jones \& Creeper 2006), including viruses (Norton et al. 1993a, Pass et al. 1988) and Perkinsus (Norton et al. 1993b).

Despite these controls, severe mortalities were reported from several farms in the Exmouth Gulf in late October 2006. The index case was reported on 23 October, and within a week high mortalities (80 to $100 \%$ ) were being reported from most other leases in Exmouth Gulf, although one lease with different ownership in 


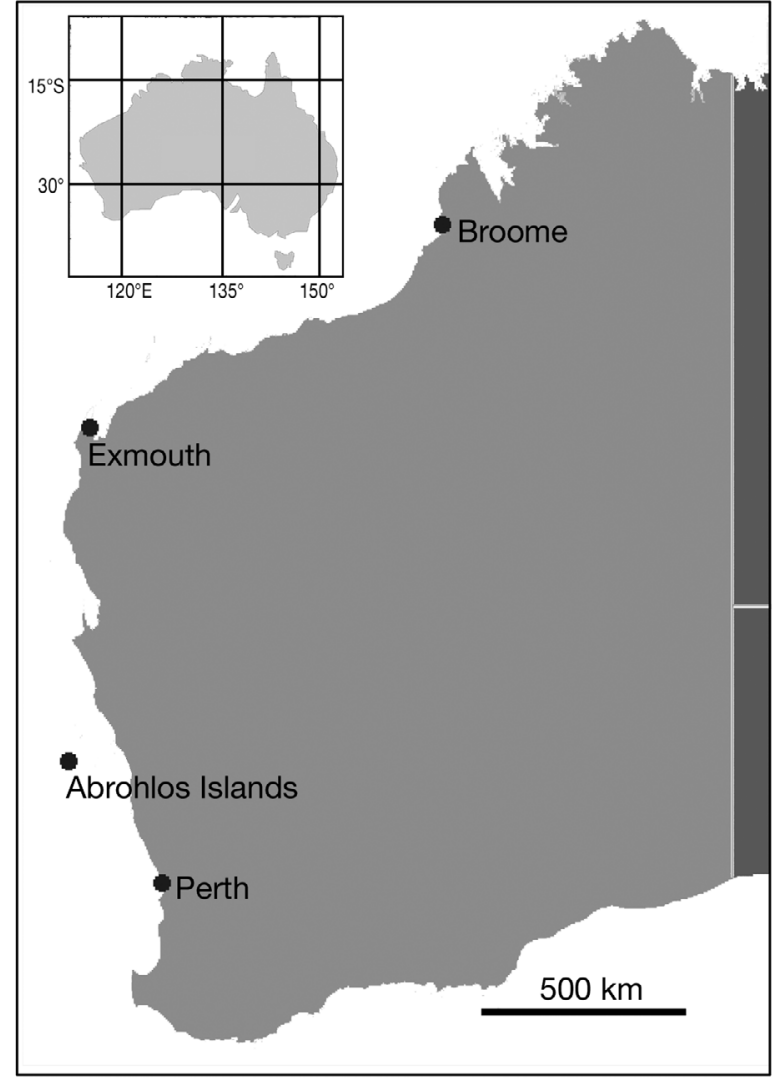

Fig. 1. Location of Exmouth (initial sampling site) in relation to main population centres, and the Abrohlos Islands, source of Akoya oysters (see 'Discussion'). Western Australia forms the western third of the Australian continent, shown as inset. The top of the inset is the Equator; the grid lines are $15^{\circ}$ longitude and latitude

the centre of the Gulf did not identify any disease for several weeks following the initial discoveries. An independent epidemiological investigation (unpublished confidential epidemiological report from the AusVet Animal Health Services for the Department of Fisheries) concluded that the outbreak pattern was consistent with a propagating epidemic. Gross signs included mantle retraction, muscle weakness, mild oedema and mortality. All sizes of shell, including seeded shell in excess of $120 \mathrm{~mm}$ diameter, were affected.

Research to identify the cause of the mortalities is ongoing. The present study describes the lesion associated with the affected oysters and reviews the implication of the oedema, apparently a common finding in diseased molluscs.

\section{MATERIALS AND METHODS}

Because of the distances involved, it is difficult to get samples to the nearest laboratory (Perth). Initial sam- ples were collected by departmental personnel who flew to the affected site; subsequent fixed samples were provided by trained industry technicians. Moribund and healthy oysters were dissected and samples for histology were immediately fixed on-site for 12 to $18 \mathrm{~h}$ with $10 \%$ seawater buffered formalin, then drained of free fixative, packed (still wet with fixative) according to International Air Transport Association regulations and air freighted to Perth (an additional 6 to $12 \mathrm{~h}$ travel time). On receipt, samples were dehydrated through alcohol series, embedded in paraffin, sectioned and stained with haematoxylin and eosin (H\&E) using standard techniques. This method has been standardised across the industry since 1994 and gives excellent results (Humphrey et al. 1998, Jones 2008).

Bacterial samples were collected from the mantle cavity of affected oysters either by the use of sterile swabs subsequently stored in transport medium, or swabbed directly onto marine soy agar plates before air freighting to the Animal Health Laboratory in Perth for culture and identification using standard techniques (Buller 2004).

Water samples (1 l) collected at the affected farms were fixed with Lugol's iodine and air freighted to Perth for examination for presence of algal blooms by the Plankton Ecology Unit of the Department of Water.

Samples were also sent for transmission electron microscopy to the Australian Animal Health Laboratory at Geelong, Victoria.

\section{RESULTS}

\section{Gross signs}

The gross appearance of the oysters in the culture panels showed mantle retraction and mild watery swelling (oedema) of the mantle tissues and palps, digestive gland, pericardial region and intestine (Fig. 2). The oysters were slow to close and high mortality (80 to $100 \%$ ) was evident, with large numbers (thousands) of freshly dead oyster shells (valves still attached at the hinge) within the submerged culture panels. It was noticeable that fish as well as other bivalves (including Pintada margaratifera and $P$. albina) settled on affected panels were apparently unaffected. No mortality events were reported in any other species of animal.

\section{Histology}

No significant pathogens were detected in histological sections. Oysters had been recently feeding, the intestine was full and the digestive diverticulae 


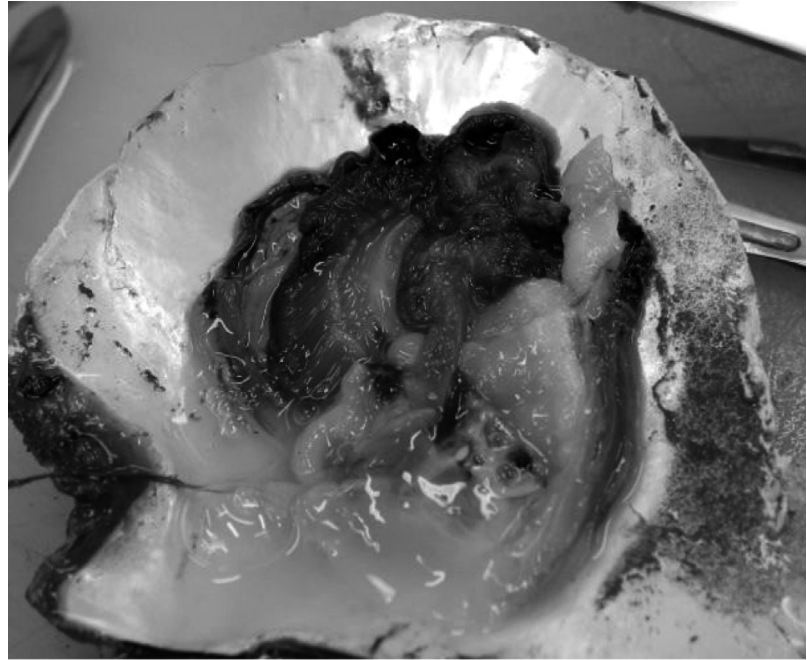

Fig. 2. Pinctada maxima. One shell removed to show oedematous appearance and severe mantle retraction, with fouling of the exposed nacre

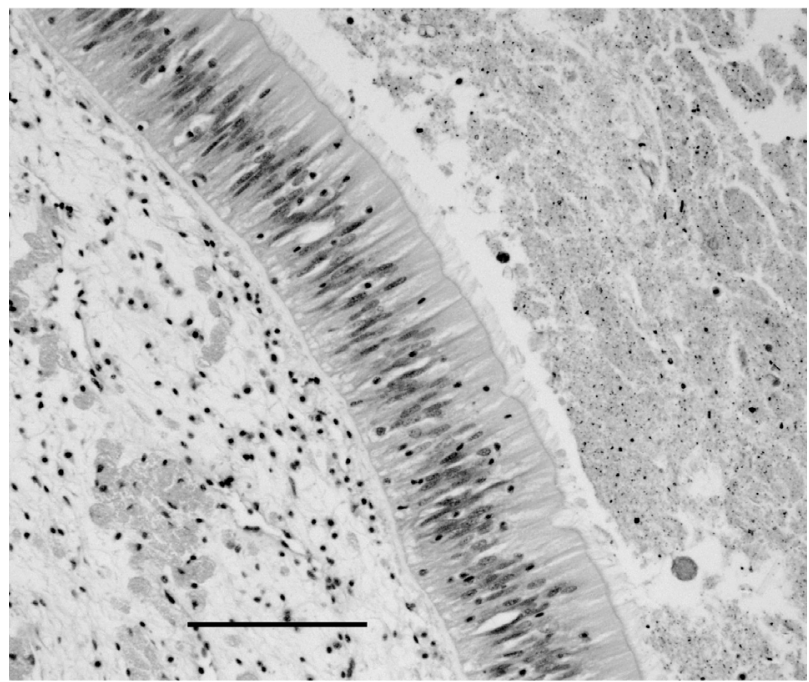

Fig. 3. Pinctada maxima. Normal histology of the intestinal epithelium, intestinal contents to right. H\&E staining. Scale bar $=0.05 \mathrm{~mm}$

showed normal feeding activity. No haemocyte inflammatory response was seen in affected oysters, but tissues showed the effects of mild oedema through the presence of swollen haemolymph channels and intercellular spaces. Examination of a large number of affected oysters (>8000) revealed that loss of epithelial cells along the mantle margins and in the stomach and intestine was not a processing artifact but was a lesion, beginning with apparent vacuolation or separation of individual epithelial cells along the basement membrane, with affected areas coalescing to slough off the epithelium in patches from the underlying tissue
(Figs. 3, 4 \& 5). It has not yet been determined if the process is internal to the cell (vacuolation) or involves separation of the cell wall from the underlying tissue layers. No nuclear inclusions or other cellular abnormalities were seen.
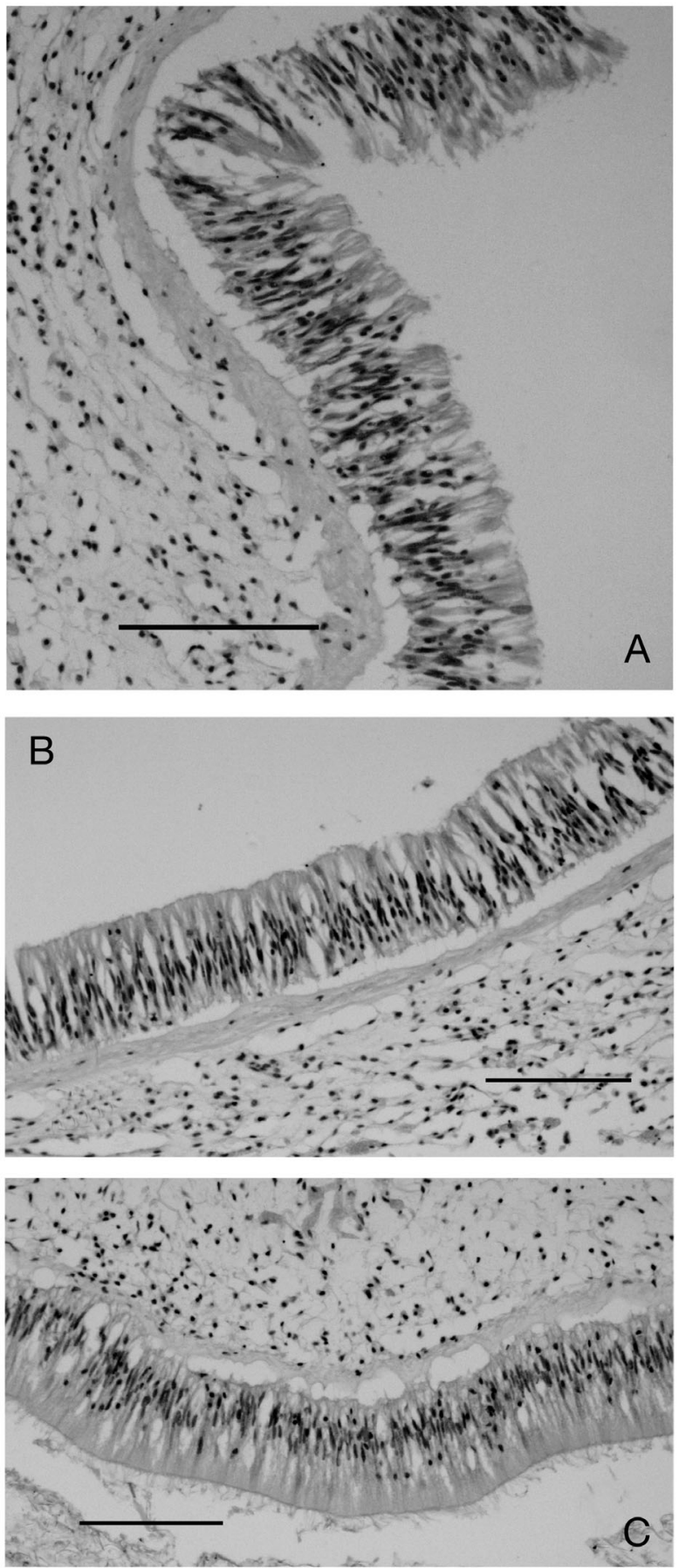

Fig. 4. Pinctada maxima. (A-C) Stomach epithelium lifting off basal membrane. Lesion appears to start as a series of spaces along the cell basal membrane (C) that coalesce (B) to lift off a patch of epithelium (A). H\&E staining. Scale bars $=0.05 \mathrm{~mm}$ 


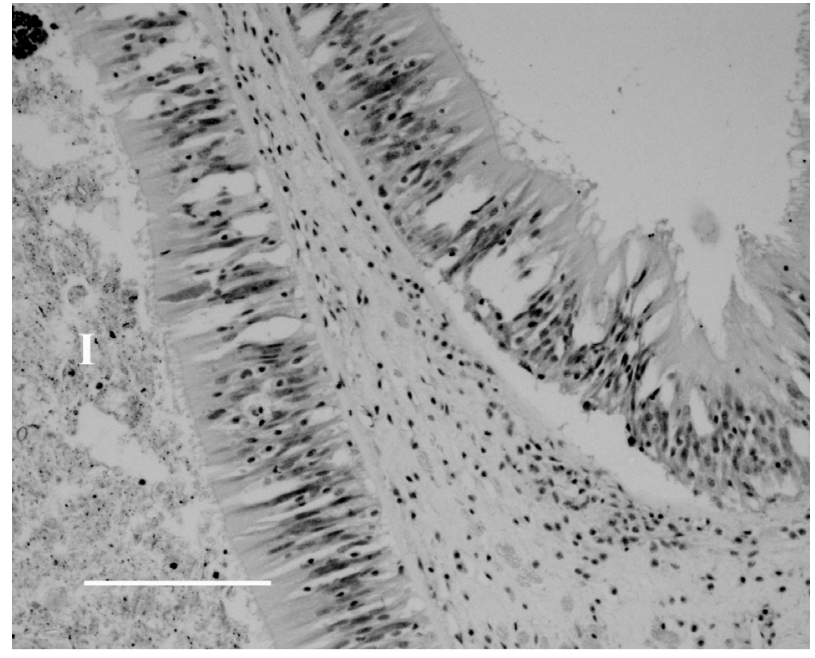

Fig 5. Pinctada maxima. Intestinal wall fold with normal epithelium on left, epithelium sloughing off at bottom right.

I: intestine contents. H\&E staining. Scale bar $=0.05 \mathrm{~mm}$

\section{Bacteriology}

Eight hundred swabs were cultured and a mixed bacterial flora was identified with Vibrio spp. dominant, mainly $V$. harveyi, $V$. mediterranei and $V$. tubiashi. There was no consistent isolate, with each farm having its own mix of bacterial flora.

\section{Water samples}

There were no toxic algae detected. The total cell counts were 123 to 223 cells $\mathrm{ml}^{-1}$ with diatoms dominant. The diatom Chaetoceros sp. was measured at between 53 and 122 cells $\mathrm{ml}^{-1}$ and the colonial prymnesiophyte cf. Phaeocystis sp. at 22 to 85 cells $\mathrm{ml}^{-1}$.

\section{Transmission electron microscopy}

Examination was inconclusive. No clearly identifiable virus was seen associated with dying cells.

\section{DISCUSSION}

The epidemiology of the 2006 mortality event was consistent with a propagating infectious process spreading from farm to farm with movements of personnel, particularly divers (data not provided). There was no indication of toxic algal blooms or water quality changes in the affected area, and only Pinctada maxima were affected. Histology was also inconsistent with a toxic algae insult. Toxic algae generally affect the digestive gland tubule of bivalves and the authors are familiar with their effects (Negri et al. 2004, Pearce et al. 2005).

Culture revealed a suite of bacteria present in moribund oysters at each site sampled, but there was no consistent pattern in the bacterial flora isolated. Vibrio spp. are the dominant bacterial flora in seas around tropical Western Australia (F. Stephens unpubl. data). In addition, the affected oysters showed no inflammatory response normally associated with bacterial and metazoan infections (Pauley \& Sparks 1965, 1966, Pass et al. 1987), and the shell nacre showed no sign of brown rings or patches associated with $V$. harveyi (Elston et al. 1999).

Mass mortalities of bivalves are relatively common and many of these are of unknown aetiology but are believed to involve an infectious process (Kurokawa et al. 1999, Nakayasu et al. 2004, Kurihara et al. 2005) and may be multifactorial (Fisher \& Moline 1988, Cheney et al. 2000, Xiao et al. 2005, Samain et al. 2007). In particular, mortalities of Japanese pearl oysters Pinctada fucata martensii have been associated with water temperature and the presence of low nutrient algae such as Nitzschia spp., as well as a putative virus, Akoya oyster disease (Tomaru et al. 2001, Nagai et al. 2007). The absence of the red-brown coloration in the adductor muscle and the dominance of the high nutrient value Chaetoceros spp. in the water column is evidence that the mortalities in Exmouth Gulf were not due to Akoya oyster disease. Necrosis of the adductor muscle, associated with Syndrome 85 in P. margaratifera from French Polynesia (Comps et al. 2001), was never observed.

The suspicion that the disease is caused by an infectious process seems to be at odds with the lack of any inflammatory response. The lack of an inflammatory response or any significant histopathology in bivalves subject to mass mortalities has been previously observed in scallops Chlamys farreri by Xiao et al. (2005), and although the aetiology of the mortalities in scallops is unknown, histological changes are reported to include cell swelling and sloughing of epithelia, for which a viral aetiology has been proposed (Wang et al. 2002, He et al. 2003, Fu et al. 2004).

The only consistent lesion seen in the affected Pinctada maxima oysters was that associated with the sloughing of the epithelia from the intestine and mantle. Such a lesion is easy to dismiss as a tissue processing artifact. Wax sections that overspread in a hot water bath can produce a similar lesion except that the separation is widespread on the slide and occurs deeper in the tissue (Fig. 6). Examination of over 8000 affected oysters has convinced the authors that the lesion is real.

Epithelial sloughing has been reported before. Mytilus edulis exposed to metal pollutants shows vac- 

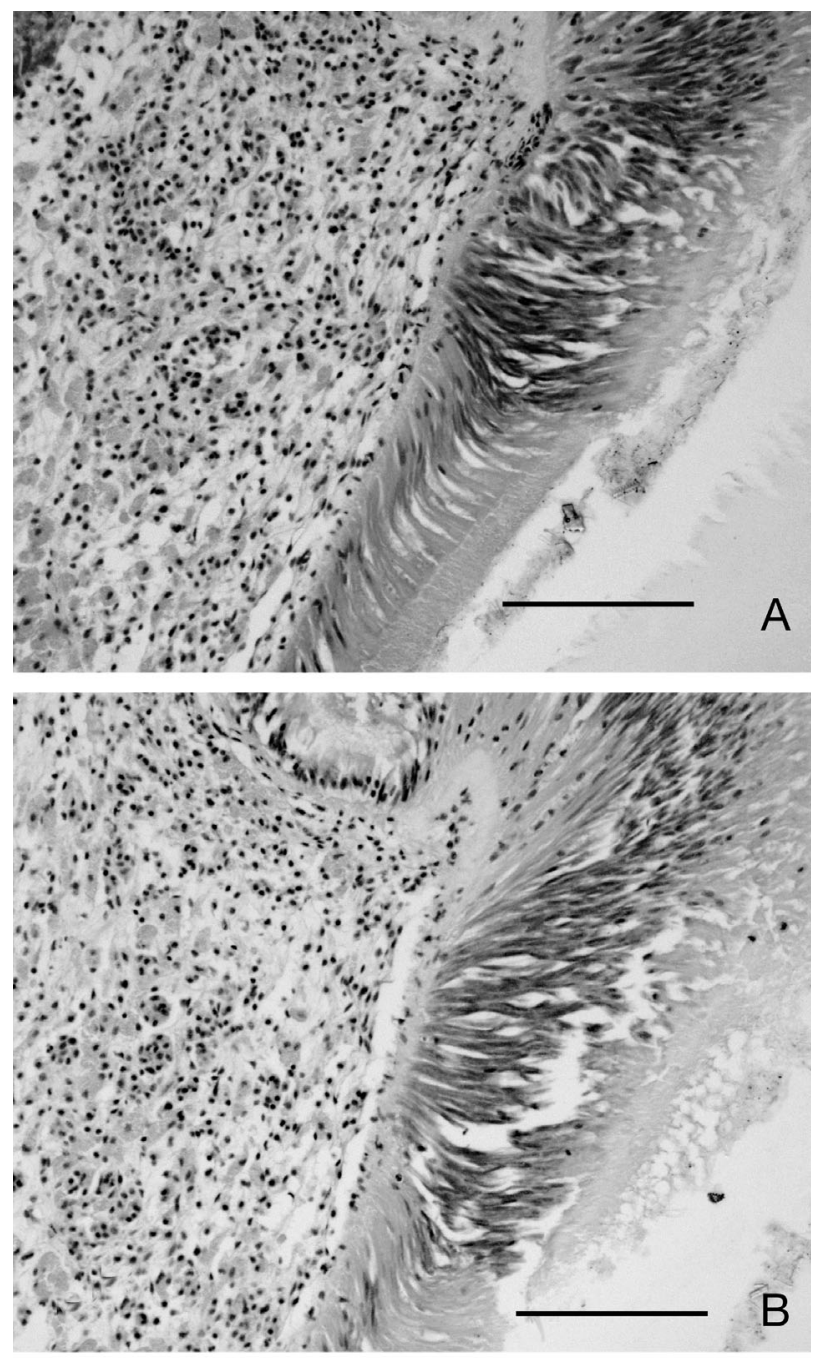

Fig. 6. Pinctada maxima. (A) Normal epithelium of stomach, correctly cut and mounted on slide. (B) Sequential section to (A), but with a hotter water bath, which has spread the wax section prior to staining (a processing artifact). Compare to Fig. 4 ; note the separation of the epithelial layer is below the muscular layer. H\&E staining. Scale bar $=0.05 \mathrm{~mm}$

uolation and sloughing of endothelial cells (Sunila 1988), as do the epithelial cells of the bent-nosed clam Macoma nasuta when exposed to the insecticide Sevin (Armstrong \& Millemann 1974). Since Exmouth Gulf is a remote species-rich heritage area and Pinctada maxima was the only species affected, pollutants are unlikely to have caused the lesion we saw. What is not clear is whether the lesion is due to a putative disease agent or is simply a result of oedema. Oedema in $P$. maxima was stated by Humphrey et al. (1998, p. 37) to be 'a degenerative response in a physiologically compromised oyster' and was reported to be seen commonly in oysters removed from the water column and held at high ambient air temperatures.
Oedema or watery tissues (Fig. 2) is a commonly described observation for sick molluscs, and has been reported, for example, in Crassostrea gigas infected with Microcytos mackini (Farley et al. 1988); as epithelial oedema and sloughing associated with oyster velar virus disease in C. gigas (Elston \& Wilkinson 1985); in Ostrea edulis and O. chilensis affected with concurrent infections including Bonamia spp. (Balouet et al. 1986, Hine 2002); and in juvenile oyster disease caused by Alphaproteobacteria (Roseovarius crassostreae) in C. virginica (Boardman et al. 2008). However, the histopathology associated with oedema is seldom described.

What is also unclear from the literature is why bivalve molluscs should become oedematous. Marine molluscs are osmoconformers and the extrapallial fluid and haemolymph remain in osmotic equilibrium with the external medium. Maintenance of osmolarity in a changing environment is confined to the individual cell activity (Gilles 1972, Fisher 1988, Taylor \& Andrews 1988, Berger \& Kharazova 1997). Molluscs are known to tolerate relatively large variations in cell volume as the salinity of the external media changes. However, to become oedematous in the absence of such external forces requires an active mechanism affecting sodium and chloride ion pumping (Wehner et al. 2003), cellular synthesis of organic molecules (Burg et al. 1996) and membrane permeability and/or mitochondria function in affected cells (Gilles 1972, Deaton 2001). In addition, oedematous changes in histology are also seen in spawning oysters and it may be that oedema is linked with the process of extruding eggs and sperm from the follicles into the ciliated genital ducts. A comparison of the oedema associated with

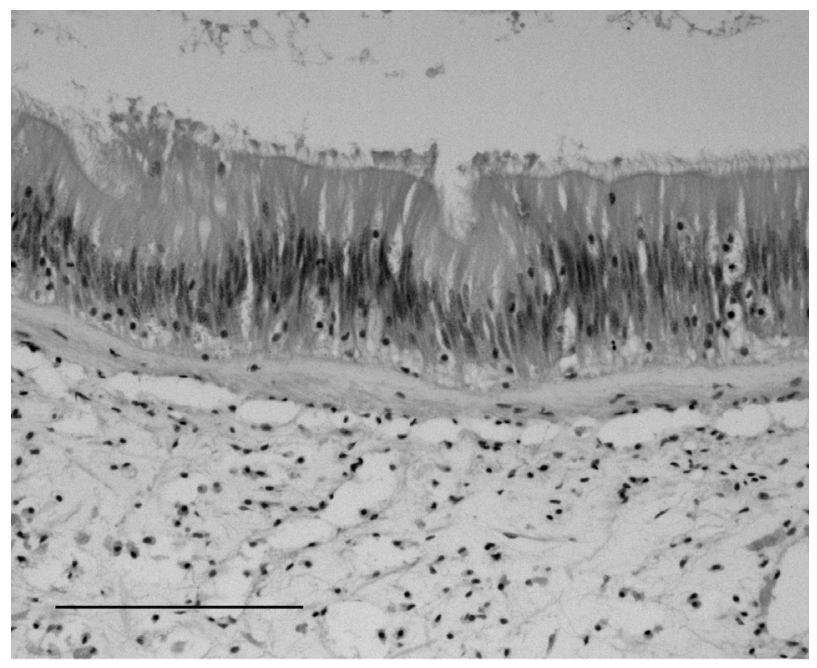

Fig. 7. Pinctada fucata. Spawning Akoya oyster tissue section showing oedema under basal muscular layer of stomach epithelium. Compare to Fig. 4. H\&E staining. Scale bar $=0.01 \mathrm{~mm}$ 
spawning Akoya oysters Pinctada fucata, taken from the Abrohlos Islands $800 \mathrm{~km}$ from the mortalities and that were seen in the oedematous $P$. maxima, shows that the location of the oedema is much deeper in the tissue of the Akoya oysters (Fig. 7). Serotonin is associated with oocyte maturation and spawning of molluscs (Fong 1998). The induction of parturition in the freshwater mussel Anodonta cygnea by incubation with serotonin reuptake inhibitors leads to an increase in water volume in the foot and the gill, producing expulsion of larvae (Cunha \& Machado 2001). Serotonin is also associated with the onset of oedema in burn victims (Samuelsson et al. 2008). Thus oedema could be mediated by a serotonin pathway, and involve the neuromuscular synapses (Cunha \& Machado 2001), which may indicate that the idea that bivalves have no power of anisosmotic extracellular regulation (Giles 1972) is wrong.

Shellfish, including bivalves, use hydraulic pressure in combination with muscles to move tissues about, such as extending the foot and mantle. The heart provides only limited, sluggish blood flow and acts as a valve to stop back pressure while the main pressure on the system is created by muscular action (Trueman 1966). Those bivalves that have been studied operate at a constant blood volume and at retraction the tissues become suffuse with haemolymph. Thus it is to be expected that sick (i.e. fully retracted and flaccid) oysters would appear oedematous with all intracellular spaces swollen with fluid. However, the pressures involved are such that tissue damage does not occur and does not explain the epithelial lifting seen in Pinctada maxima.

The aetiology of the lesion associated with oyster oedema disease is unclear. It could be due to a pathogenic agent affecting the epithelial cells directly, resulting in oedema, or it could be that a variety of insults (including pathogens) in molluscs provoke a generalized oedematous response either at the cellular level or through a neuroendocrine-mediated response. Oedema could also be the outcome of a flaccid hydraulic system, perhaps indicating a loss of muscular control.

Work is ongoing to determine the cause of the mortalities. However, it is apparent that there is a considerable amount of basic anatomical and physiological work still to be done to understand the process of fluid regulation in marine bivalves. It would be useful if authors could be more descriptive about what constitutes the oedema they report to be associated with osmotic changes, spawning and disease.

Acknowledgements. We thank P. Hillier, Department of Fisheries fisheries officers and the pearl company staff at the affected farms for collecting and dispatching the samples to Perth. The algal samples were analysed by the Plankton Ecol- ogy Unit of the Department of Water, and the bacteria were identified by N. Buller and staff at the Department of Agriculture and Food. We are grateful to A. Hyatt of the CSIRO Australian Animal Health Laboratory, who spent many hours in a fruitless search of oyster tissues for virus.

\section{LITERATURE CITED}

Armstrong DA, Millemann RE (1974) Pathology of acute poisoning with the insecticide Sevin in the bent-nosed clam, Macoma nasuta. J Invert Pathol 24:201-212

Balouet G, Poder M, Cahour A, Auffret M (1986) Proliferative hemocytic condition in European flat oysters (Ostrea edulis) from Breton coasts: a 6-year survey. J Invertebr Pathol 48:208-215

Berger VJ, Kharazova AD (1997) Mechanism of salinity adaptions in marine molluscs. Hydrobiologia 355:115-126

Boardman CL, Maloy AP, Boettcher KJ (2008) Localization of the bacterial agent of juvenile oyster disease (Roseovarius crassostreae) within affected eastern oysters (Crassostrea virginica). J Invertebr Pathol 97:150-158

Buller NB (2004) Bacteria from fish and other animals: a practical identification manual. CABI, Wallingford

Burg MB, Kwon ED, Kültz D (1996) Osmotic regulation of gene expression. FASEB J 10:1598-1606

Cheney DP, MacDonald BF, Elston RA (2000) Summer mortality of Pacific oysters, Crassostrea gigas (Thunberg): initial findings on multiple environmental stressors in Puget Sound, Washington, 1998. J Shellfish Res 19:353-359

Comps M, Herbaut C, Fougerouse A, Laporte F (2001) Progress in pathological characterisation of syndrome 85 in the black-lip pearl oyster Pinctada margaratifera. Aquat Living Resour 14:195-202

Cunha EM, Machado J (2001) Parturation in Anodonta cygnea induced by selective serotonin reuptake inhibitors (SSRis). Can J Zool 79:95-100

> Deaton LE (2001) Hyperosmotic volume regulation in the gills of the ribbed mussel Geukensia demissa: rapid accumulation of betaine and aniline. J Exp Mar Biol Ecol 260: 185-197

Elston RA, Wilkinson MT (1985) Pathology, management and diagnosis of oyster velar virus disease (OVVD). Aquaculture 48:189-210

Elston RA, Frelier P, Cheney D (1999) Extrapallial abscesses associated with chronic bacterial infections in the intensively cultured juvenile Pacific oyster Crassostrea gigas. Dis Aquat Org 37:115-120

Farley CA, Wolf PH, Elston RA (1988) A long-term study of 'microcell' disease in oysters with a description of a new genus, Mikrocytos (g. n.), and two new species, Mikrocytos mackini (sp. n.) and Mikrocytos roughleyi (sp. n.). Fish Bull 86:581-593

Fisher WS (1988) Environmental influence on bivalve haemocyte function. In: Fisher WS (ed) Disease processes in marine bivalve molluscs. Am Fish Soc Spec Publ 18: 225-237

Fisher WS, Moline MA (1988) Stress, acclimation, and seasonal changes in defense-related oyster hemocyte activities. J Shellfish Res 7:157 (Abstract)

> Fong PP (1998) Zebra mussel spawning is induced in low concentrations of putative serotonin reuptake inhibitors. Biol Bull 194:143-149

Fu CL, Song WB, Li Y, Zhang YZ, Yan HC (2004) Histopathological research and immunofluorescence of AVND virus infection in cultured scallop Chlamys farreri. Acta Microbiol Sin 44:741-744 (in Chinese with English Abstract) 
Gilles R (1972) Osmoregulation in three molluscs: Acanthochitona discrepans (Brown), Glycymeris glycymeris (L.) and Mytilus edulis (L.). Biol Bull 142:25-35

He G, Li Y, Song W, Wang C, Huang J, Wang X (2003) The relationship between the pathogenic infection status and mortality of the scallop Chlamys farreri. J Fish China 27: 273-277

Hine PM (2002) Severe apicomplexan infection in the oyster Ostrea chilensis: a possible predisposing factor in bonamiosis. Dis Aquat Org 51:49-60

Humphrey JD, Norton JH, Jones JB, Barton MA, Connell MT, Shelley CC, Creeper JH (1998) Pearl oyster (Pinctada maxima) aquaculture: health survey of Northern Territory, Western Australia and Queensland pearl oyster beds and farms. FRDC Final Report 94. Fisheries Research Development Corporation, Canberra

Jones JB (2008) The Australian experience: pearl oyster mortalities and disease problems. In: Bondad-Reantaso $\mathrm{M}$, McGladdery SE, Berthe FCJ (eds) Manual on South Sea pearl oyster health management. FAO Fish Tech Pap 503:87-93

Jones JB, Creeper J (2006) Diseases of pearl oysters and other molluscs: a western Australian perspective. J Shellfish Res 25:233-238

Kurihara T, Simizu H, Tamaki M, Hayashibara T and others (2005) Patterns, causes and prevention of mass mortality of juvenile blacklip pearl oyster Pinctada margaratifera (L.) cultured in Okinawa, subtropical Japan. Proceedings of the 32nd US Japan Symposium on aquaculture meeting, 17-20 Nov 2003, Davis and Santa Barbara, CA, p 101-119. NOAA, Maryland

Kurokawa H, Suzuki T, Okauchi M, Miwa S and others (1999) Experimental infections of a disease causing mass mortalities of Japanese pearl oyster Pinctada fucata martensii by tissue transplantation and cohabitation. Bull Jpn Soc Sci Fish 65:241-251 (in Japanese with English Abstract)

Nagai K, Go J, Segawa S, Honjo T (2007) A measure to prevent relapse of reddening adductor disease in pearl oysters (Pinctada fucata martensii) by low-water temperature culture management in wintering fisheries. Aquaculture 262:192-201

Nakayasu C, Aoki H, Nakanishi M, Yamashita H, Okauchi M, Oseko N, Kumegai A (2004) Tissue distribution of the agent of Akoya disease in Japanese pearl oyster Pinctada fucata martensii. Fish Pathol 39:203-208

Negri AP, Bunter O, Jones B, Llewellyn L (2004) Effects of the bloom-forming algae Trichodesmium erythraeum on the pearl oyster Pinctada maxima. Aquaculture 232:91-102

Norton JH, Shepherd MA, Prior HC (1993a) Papovavirus-like infection of the golden-lipped pearl oyster, Pinctada maxima, from the Torres Strait, Australia. J Invertebr Pathol 62:198-200

Norton JH, Shepherd MA, Perkins FP, Prior HC (1993b) Perkinsus-like infection in farmed golden-lipped pearl oyster, Pinctada maxima, from the Torres Strait, Australia. J Invertebr Pathol 62:105-106

Pass DA, Dybdahl R, Mannion MM (1987) Investigations into the causes of mortality of the Pearl oyster, Pinctada maxima (Jamison) in Western Australia. Aquaculture 65: 149-169

Pass DA, Perkins FP, Dybdahl R (1988) Virus-like particles in the digestive gland of the pearl oyster (Pinctada maxima). J Invertebr Pathol 51:166-167

Pauley GB, Sparks AK (1965) Preliminary observations on the acute inflammatory reaction in the Pacific oyster, Crassostrea gigas (Thunberg). J Invertebr Pathol 7:248-256

Pauley G, Sparks AK (1966) The acute inflammatory reaction in two different tissues of the Pacific oyster, Crassostrea gigas. J Fish Res Board Canada 23:1913-1921

Pearce I, Handlinger JH, Hallegraeff GM (2005) Histopathology in Pacific oyster (Crassostrea gigas) spat caused by the dinoflagellate Prorocentrum rhathymum. Harmful Algae 4:61-74

Samain JF, Dégremont L, Soletchnik P, Haure J and others (2007) Genetically based resistance to summer mortality in the Pacific oyster (Crassostrea gigas) and its relationship with physiological, immunological characteristics and infection processes. Aquaculture 268:227-243

Samuelsson A, Abdiu A, Wackenfors A, Sjöberg F (2008) Serotonin kinetics in patients with burn injuries: a comparison between the local and systemic responses measured by microdialysis - a pilot study. Burns 34: $617-622$

Sunila I (1988) Acute historical responses of the gill of the mussel, Mytilus edulis, to exposure by environmental pollutants. J Invertebr Pathol 52:137-141

Taylor PM, Andrews EB (1988) Osmoregulation in the intertidal gastropod Littorina littorea. J Exp Mar Biol Ecol 122: $35-46$

Tomaru Y, Kawabata Z, Nakano S (2001) Mass mortality of the Japanese pearl oyster Pinctada fucata martensii in relation to water temperature, chlorophyll $a$ and phytoplankton composition. Dis Aquat Org 44:61-68

Trueman ER (1966) The fluid dynamics of the bivalve molluscs, Mya and Margaratifera. J Exp Biol 45:369-382

Wang C, Wang X, Song X, Wang Y, Huang J, Song W (2002) Possible virus-like aetiology causing massive death of scallop Chlamys farreri in North China. World Aquaculture 2002, Bejing, 23-27 Apr 2002. World Aquaculture 2002 Book of Abstracts, World Aquaculture Society, Beijing, p 777

Wehner F, Olsen H, Tinel H, Kinne-Saffran E, Kinne RKH (2003) Cell volume regulation: osmolytes, osmolyte transport, and signal transduction. Rev Physiol Biochem Pharmacol 148:1-80

Xiao J, Ford S, Hongsheng Y, Zhang G, Zhang F, Guo X (2005) Studies on mass summer mortality of cultured Zhikong scallops (Chlamys farreri Jones et Preston) in China. Aquaculture 250:602-615

Submitted: December 15, 2009; Accepted: April 12, 2010

Proofs received from author(s): June 22, 2010
Editorial responsibility: Eugene Burreson,

Gloucester Point, Virginia, USA

\author{
Proofs received from author(s): June 22,2010
}

